\title{
Macroeconomic Fluctuations, Foreign Aid Shocks and the Forecast of Economic Growth Rate in Nigeria
}

\author{
Ayeni, R. K. (Ph.D) \\ Department of Economics, Ekiti State University, Ado Ekiti, Nigeria
}

\begin{abstract}
The study examined effectiveness of foreign aid flows also called official development assistance in increasing economic growth in Nigeria. The main objective was to empirically analyze the impact of foreign aid flow and its domestic saving counterpart on the economic growth in Nigeria under the assumption of stable and unstable macroeconomic indicators with the aim of knowing what determines the effectiveness of official development assistance in an economy. Time series data were used sourced from various sources such as the Central Bank of Nigeria statistical bulletin, and World Bank databank. The study employed Augmented Dickey fuller (ADF) to ascertain the stationarity of the time series properties of the research variables. The study made use of Auto-regressive distributed lag (ARDL) Bound Testing approach to co-integration error correction mechanisms(ECM) to determine the dynamic relationship between foreign aid flows and Economic growth in Nigeria. VAR and Granger Causality tests were used to explain the transmission of socks among the variable and to forecasts economic growth rate and official development assistance effectiveness. The findings from the study reveal that there is disequilibrium in the growth rate of GDP in Nigeria. In the short-run the combination of domestic saving and foreign aid variables tend to correct the disequilibrium but at slow speed of adjustment. Given all macroeconomic indicators in Nigeria as stable, domestic saving and foreign aid are more effective to increase the growth of the economy. With the unstable nature of macroeconomic indicators in Nigeria especially, the increasing rate of inflation and exchange rates and the low export rate, official development assistance, that is foreign aid, tend to be impacting negatively on the economy rather than positive. That means foreign aid becomes less effective in the face of unstable exchange rate, inflation rate and low export. Based on the findings, the study recommends that, Policy measures that will diversify the economy, improve export and encourage a more stable exchange rate should be put in place to allow a more effective utilization of foreign aids in the economy.
\end{abstract}

Keywords: GDP growth rate, Official Development Assistance, Saving rate, Exchange rate, ARDL

\section{Introduction}

Foreign aid or foreign assistance, by definition, are designed to promote economic development and welfare and are provided as either grants or subsidized loans by Development Assistance Committee (DAC) of the Organization for Economic Cooperation and Development (OECD).The DAC classifies foreign aid flows into three broad categories. Official development assistance (ODA) which is the largest, consisting of aid provided by donor governments to low- and middle-income countries. Official assistance (OA) is aid provided by governments to richer countries with per capita incomes higher than approximately $\$ 9,000$ (e.g., Bahamas, Cyprus, Israel and Singapore) and to countries that were formerly part of the Soviet Union or its satellites. Private voluntary assistance includes grants from non-government organizations, religious groups, charities, foundations, and private companies.

The global community has long considered that developing countries need a vast inflow of foreign resources in order to fill the savings and foreign exchange gaps associated with a rapid rate of capital accumulation and growth needed to prevail widespread poverty and to increase living standards. The various form of inflow of foreign aid was welcome in developing countries to bridge the gap between savings and domestic investment and therefore, to accelerate growth [1].Foreign assistance has significant role for every national economy regardless of its level of development. For the developing countries, it is used to increase accumulation and rate of investments to create conditions for more intensive economic growth. Even the international community shares the view that foreign capital inflow to developing countries is necessary to foster economic development and poverty eradication. For example, in the 1999, former United Nations (UN) Secretary General, Koffi Annan while delivering a speech in the World Economic forum in Davos, Switzerland proposed that state; private investors and civil society should join hands together to achieve economic development.

Nigeria is a country which is well endowed with both human and natural resources; a country that was known to be a largest exporter of agricultural commodities like cocoa, coffee and rubber and among others. But, since the discovery of oil booms in the year 1958, Nigeria has mostly depended on proceeds from the sale of crude oil at the expense of other productive sectors such as solid minerals (tin, iron ore, coal, limestone, 
bitumen, niobium, lead, zinc etc.), which are available, manufacturing and agriculture. The country's overdependence on oil amidst the declining state of other productive sectors has weakened the non-oil sector of the economy. This has also classified Nigeria under the developing economies meant to enjoy the first category of foreign aid, that ids the official development assistance.

Furthermore, the tremendous revenue accruing from oil and mismanagement of such revenue realized has reduced Nigeria to a mono-cultural economy. This made Nigeria economy productive capacity runs below expectation and led to inadequate savings and deteriorating terms of trade, high exchange rate, inflation rate and unemployment rate. The economy entered a recession recently. As at December 2016, inflation rate was 18.55, parallel exchange rate was about 485 naira to a dollar and the growth rate was negative. GDP annual growth rate in Nigeria fell from $2.11 \%$ in the last quarter of 2015 to $-0.36 \%$, in the first quarter of 2016, and further to -2.06 and -2.24 in the second and third quarters of 2016 respectively [2] The world investment report captures Nigeria as the top FDI destination in Africa in 2011, with $\$ 8.92 \mathrm{bn}$, up from $\$ 6.10 \mathrm{bn}$ recorded in 2010. South Africa is next with \$5.81bn while Ghana \$3.22bn, Congo \$2.93bn and Algeria \$2.57bn [3]. Also between 2014 and 2016 , Nigeria ranked second among the top ten African countries that enjoyed official development assistance as shown in Table 1 below.

Table 1: Top 10 ODA Recipients by Recipient in Africa

\begin{tabular}{|c|c|c|c|}
\hline Country & USD million & Percentage & Ranking \\
\hline Ethiopia & 3585 & 7 & \multirow[t]{2}{*}{$1^{\text {st }}$} \\
\hline Egypt & 3532 & 7 & \\
\hline Kenya & 2665 & 5 & \multirow[t]{3}{*}{$2^{\text {nd }}$} \\
\hline Tanzania & 2648 & 5 & \\
\hline Nigeria & 2476 & 5 & \\
\hline D R Congo & 2398 & 4 & \multirow[t]{4}{*}{$3^{\text {rd }}$} \\
\hline Morocco & 2247 & 4 & \\
\hline Mozambique & 2103 & 4 & \\
\hline South Sudan & 1964 & 4 & \\
\hline Uganda & 1633 & 3 & $4^{\text {th }}$ \\
\hline other recipients & 28941 & 53 & \\
\hline Total & 54193 & 100 & \\
\hline
\end{tabular}

Despite the fact that Nigeria is one of the top destination of official development assistance in Africa, it is still incredible that we could not ascertain and confirm where those foreign capital are being channeled because Nigeria economy is still suffering from lack of infrastructural facilities, hostile environment, backwardness in technology, problem of unemployment and over-dependence on imported products amongst other factors and recently in economic recession. As the economy of Nigeria recently dropped to a recession, it is therefore, essential to empirically investigate whether the role of foreign aid with respect to the economic growth, can help revive the economy in the long-run. One of the main reasons for giving foreign aid, the most notable argument is to bridge the gap between domestic saving and domestic investment and therefore, to accelerate growth.Based on these observations on foreign aid flows and economic growth in Nigeria, we raise two major empirical questions: "does foreign aid flows promote or retard economic growth?" and, "Under what macroeconomic conditions does foreign aid and saving rate become more effective to increase the growth rate of the economy?" Thus, this paper attempts to answer the above questions by empirically analysing the impact of foreign aid flow and its domestic saving counterpart on the economic growth in Nigeria under two major assumptions. The first is the "stable macroeconomic indicators assumption", while the second is the "unstable macroeconomic indicators assumption."

\section{Brief Review Of Literature}

[3], examined aid, macroeconomic policy environment and growth in sub-Saharan Africa, using a panel regression model covering twenty Sub-Saharan African countries. His estimation was done with OLS and TSLS over a period of 1970 to 2001 . His empirical finding showed that a sound macroeconomic environment is sine qua non for the effective contribution of aid to sustainable growth.

[4], analyzed the impact of foreign aid on economic growth in Nigeria for the period 1970-2010, using cointegration techniques and the empirical analyses rely on the neo-classical approach. Empirical finding shows that aid flows has significant impact on economic growth in Nigeria.

[5], re-examined foreign aid led growth in West Africa. The study concluded that panel co-integration results indicate a long run relationship between aid and growth in the whole panel. There is evidence of unidirectional causality from foreign aid to economic growth, and from economic growth to foreign aid and there are cases where both variables are independent. 
[6], investigates the correlation between foreign aid and growth in per capita GDP using annual data from the 1960 to 1997 for a sample of 71 aid-receiving developing countries. This paper concludes that the effect of foreign aid on economic growth is positive, permanent, and statistically significant.

[7], address directly the mechanisms via which aid impacts growth. Using panel data for sample of 25 SubSaharan African countries over the period 1970 to 1997, the authors determined that foreign aid has a significant positive effect on economic growth.

[8], use panel VAR analysis as well as Granger causality test for identifying the links between the capital flows and growth along with savings for 18 Asian and Latin American developing countries over the period of 19711994 which suggests that this link exists.

[9], with the use of panel data regression, attempted to quantify the impact of foreign aid on economic growth in developing countries over the period 1975-2000. Making use of cross-country data comprising thirty-nine countries, he found evidence that foreign aid significantly and negatively correlates with growth in developing countries.

[10], examines the interplay of foreign aid, external debt and economic growth in Nigeria, covering the period 1970 - 2008, using seemingly unrelated regression estimation (SURE) model and the results show that foreign aid has positive impact on growth in Nigeria.

[11], examined an empirical analysis of the impact of foreign aid on capital generation in Nigeria ranging from 1980 - 2013, using Ordinary Least Squared (OLS) technique and the results derived showed that foreign aid contributed negatively to capital generation in Nigeria and the accompanying variable which was external debt also has a negative contribution to capital generation.

[12], examined foreign aid, Domestic savings and Economic growth in South Asia, covering the period 1960 to 2008, using simultaneous equation system and the result indicate that aid has positive and significant effect on the growth rates of the five nations studied.

[13], analysis the interactive effect of aid and policy sustainable economic growth in Zimbabwe from $1990-$ 2010, using Ordinary Least Square (OLS) technique and the result shows that foreign aid and real GDP (economic growth) have a negative relationship.

[14], examined the impact of foreign aid and domestic savings on economic growth in the WAMZ countries, covering the period 1980 to 2012, using panel data Analysis and the results indicate foreign aid is negatively related with economic growth.

[15], examine the impact of foreign capital flows on the growth performance of the Nigeria economy, over the period 1982 - 2012, using multiple regression analysis and the empirical results shows that foreign capital inflows had a positive and significant effect on economic growth.

[16], Examined the link between foreign aid and economic growth in Nigeria, covering the period 1981 to 2012 , using ordinary least square, Augmented Dickey Fuller (ADF) test, Johansen co-integration test and the result shows a negative and non-significant relationship between foreign aid to Nigeria and GDP.

[17], examined the relationship between foreign direct investment and economic growth in 68 developing countries ,using panel data, covering the period 1970 - 1980 and the result shows that negative relationship exist between foreign direct investment and economic growth.

[18], examined the nexus between foreign direct investment and economic growth in 32 countries (15 OECD and 17 non- OECD), using panel data, covering the period $1970-1990$ and the empirical findings show (positive for OECD but negative effect for non- OECD).

[19], examines the effectiveness of foreign aid, foreign direct investment and economic growth in selected 28 Asian countries, covering the period 1998 - 2007, using static and dynamic panel data techniques and the result shows that inflow of foreign direct investment and foreign aid were significant factors negatively affecting economic growth.

[20], in a study of 77 countries over sub-periods 1971-1980, 1981-1990 and 1971-1990, show that foreign aid positively affects economic growth in developing countries. This is consistent with theory of foreign aid, which asserts that overseas development assistance accelerates economic growth by supplementing domestic capital formation [1].

[21], conduct a causality test between foreign aid and economic growth for four Asian and four African countries and find that except for Kenya and Nepal, foreign aid is positively and significantly related to economic growth.

\section{Theoretical Background, Model Specification And Estimation}

Two-Gap Analysis was employed as the theoretical framework for our model. The Two-Gap analysis of development is contained in the Post-Keynesian growth models for closed economies as designed by Harrod and Domar. They tried to identify the pre-conditions for the economic growth of market economies as domestic savings and foreign aid. These two preconditions are essentially rooted in the Nigerian economy and these are characterized by inadequate domestic savings which definitely has effect on investment thereby resulting in the 
SAVING GAP. To close this gap according to the model requires foreign aid flows. Nigeria is also characterized by insufficient foreign earnings arising from inability to export vis-à-vis high importation leading to short fall in foreign exchange. This leads to a foreign exchange constraint called a TRADE GAP. This can be corrected by foreign aid. The two-gap model of growth has been adopted by many authors as a tool to bring economy to bear on the path of growth and if possible, liberate the economy.

This study builds on the work of [18], which took its root from two-gap modelwith little modification. The model specification considers the Gross domestic product growth rate (GDPGR) as dependent variable, while Foreign aid proxy with Official Development Assistance (ODA), inflation rate (INF), Exchange rate (EXR), Export (EXP), Savings rate (SA), are independent variables. Two forms of the model were specified as a modification to previous authors' specifications. The first form specified economic growth rate as solely a function of domestic saving rate (SAV) and foreign assistance rate (official development assistance ODA) as suggested by the two gap model, holding other macroeconomic variables constant. This is shown in equation 1 .

$$
G D P G R_{t}=f\left(S A V_{t}, O D A R_{t}\right) \ldots .1
$$

The second form of the model is specified relaxing the assumption of constant macroeconomic indicators as currently witnessed in the Nigeria economy, high rate of inflation, high exchange rate, and low export rate. The model is specified thus;

$$
G D P G R_{t}=f\left(S A V_{t}, O D A R_{t}, I N F_{t}, E X R_{t}, E X P R_{t}\right) \ldots 2
$$

The study employed the cointegration and the vector error correction techniques to measure the long run equilibrium and the short-run dynamic relationships among the variables. Equations 1 and 2 are stated explicitly as follows: $\begin{aligned} & g d p_{t}=\alpha_{0}+\alpha_{1} \operatorname{sav}_{t}+\alpha_{2} \text { odar }_{t}+e_{t} \ldots .3 .0 \\ & g d p_{t}=\beta_{0}+\beta_{1} \text { inf }_{t}+\beta_{2} \text { exr }_{t}+\beta_{3} \exp r_{t}+\beta_{4} \text { sav }_{t}+\beta_{5} \text { odar }_{t}+e_{t} \ldots .4 .0\end{aligned}$

Where;

gdpgr $=$ Gross Domestic Product Growth rate

inf $=$ inflation rate

exr $=$ exchange rate

expr $=$ export rate

sav = savings rate

oda $=$ official development assistance, a measure of foreign aid .

This study used annual data on Gross Domestic Product growth rate, Official Development Assistance, Export Rate, and Saving rate. The data were sourced from World Bank data bank while other variables such as Exchange rate (EXR), Rate of Inflation (INF) included as macroeconomic control variables were sourced from Central Bank of Nigeria (CBN) statistical bulletin. To get a better result of fitting and make these variables in the same order of magnitude, we make appropriate transformations to GDP, Export and ODA, whose units are billion while the inflation rate and EXR stay the same.

$$
\begin{aligned}
& X_{i} \text { growth }=100 * \log \left(\frac{X_{t}}{X_{t-1}}\right) \\
& \text { where } X=g d p, \exp , \text { oda }
\end{aligned}
$$

\section{Descriptive Statistics Of Data}

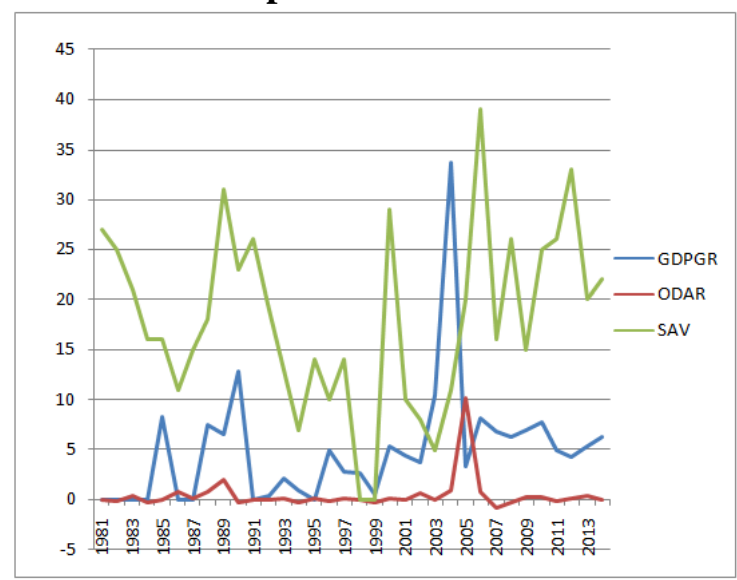

Fig. 1.0: Comparative Trend Analysis of Growth rate, Saving rate and Foreign Aid 
From the trend analysis above GDP growth rate (GDPGR) appears to be more volatile than the official development assistance growth rate (ODAR) a proxy for foreign aid. The rate at which foreign aid grows is slower than the growth rate of the economy. Foreign aid seems to be very low between 1990 and 2003. These periods were the military regimes when Nigeria suffered series of diplomatic sanctions that did not favour foreign aids. There is a jump in GDP growth rate between 2003 and 2005 and from 2011 and in foreign aid in 2005 in figure 1 . These periods were the period of restoration of civilian government in Nigeria; hence sanctions were removed on the Nigeria economy that attracted international assistance. It is to be observed also that while official development assistance remained stable between 2007 and 2014, growth rate of the economy fluctuates. Economic growth rate in Nigeria became negative in 2016 despite the continuous flow of development assistance into the economy.

\section{Empirical Results And Discussion}

To test for stationarity of the variables, the Augmented Dickey Fuller (ADF) unit root test was conducted on each series. Accordingly the null hypothesis in each case is that there is a unit root in each series that is each variable is non-stationary. The result is presented in Table 2. From the result in Table 2, ADF test shows that GDPGR, SAV and ODAR are stationary at levels while other variables, EXR, INF and EXPR are stationary at first difference. That means the condition for Johansen cointegration technique is met for equation 3 but not met for equation 4. The results of the Johannsen cointegration technique for equation 3 are reported in Tables 3 and 4 .

Table 2: ADF Unit Root Test Result

\begin{tabular}{|c|c|c|c|c|c|c|c|}
\hline \multirow[b]{2}{*}{ Variable } & \multicolumn{3}{|l|}{ At levels } & \multicolumn{3}{|c|}{$1^{\text {st }}$ Difference } & \\
\hline & ADF Test & $1 \% \mathrm{CV}$ & $5 \% \mathrm{CV}$ & ADF Test & $1 \% \mathrm{CV}$ & $5 \% \mathrm{CV}$ & $\begin{array}{l}\text { Level of } \\
\text { Integration }\end{array}$ \\
\hline GDPGR & -4.66887 & -3.6463 & -2.954 & & & & $\mathrm{I}(0)$ \\
\hline EXR & -0.07619 & -3.6463 & -2.954 & -5.4056 & -3.6537 & -2.9571 & $\mathrm{I}(1)$ \\
\hline SAV & -3.94441 & -3.6463 & -2.954 & & & & $\mathrm{I}(0)$ \\
\hline INF & -2.70757 & -3.6463 & -2.954 & -5.2618 & -3.6537 & -2.9571 & $\mathrm{I}(1)$ \\
\hline EXPR & -2.6885 & -3.6463 & -2.954 & -8.5058 & -3.6537 & -2.9571 & $\mathrm{I}(1)$ \\
\hline ODAR & -5.04103 & -3.6463 & -2.954 & & & & $\mathrm{I}(0)$ \\
\hline
\end{tabular}

Table 3.: Unrestricted Cointegration Rank Test (Trace)

\begin{tabular}{|l|l|l|l|l|}
\hline \multicolumn{6}{|l|}{ Unrestricted Cointegration Rank Test (Trace) } \\
\hline $\begin{array}{l}\text { Hypothesized } \\
\text { No. of CE(s) }\end{array}$ & Eigenvalue & $\begin{array}{l}\text { Trace } \\
\text { Statistics. }\end{array}$ & $\begin{array}{l}0.05 \text { Critical } \\
\text { Value }\end{array}$ & Prob.** \\
\hline None ${ }^{*}$ & 0.592613 & 52.50034 & 42.91525 & 0.0042 \\
\hline At most 1 & 0.355288 & 23.76463 & 25.87211 & 0.0894 \\
\hline At most 2 & 0.261913 & 9.718196 & 12.51798 & 0.1406 \\
\hline \multicolumn{6}{|l|}{ Trace test indicates 1 cointegrating eqn(s) at the 0.05 level } \\
\hline
\end{tabular}

Table 4: Unrestricted Cointegration Rank Test (Maximum Eigenvalue)

\begin{tabular}{|l|l|l|l|l|}
\hline Cointegration Rank Test (Maximum Eigenvalue) \\
\hline $\begin{array}{l}\text { Hypothesized } \\
\text { No. of CE(s) }\end{array}$ & Eigenvalue & Max- Eigenvalue Statistic & $\begin{array}{l}0.05 \text { Critical } \\
\text { Value }\end{array}$ & Prob.** \\
\hline None ${ }^{*}$ & 0.592613 & 28.73571 & 25.82321 & 0.0201 \\
\hline At most 1 & 0.355288 & 14.04643 & 19.38704 & 0.2511 \\
\hline At most 2 & 0.261913 & 9.718196 & 12.51798 & 0.1406 \\
\hline \multicolumn{6}{|l|}{ Max-eigenvalue test indicates 1 cointegrating eqn(s) at the 0.05 level } \\
\hline
\end{tabular}

Both the trace test and the maximum eigenvalue tests report that there is one cointegrating equation in equation 3. The normalized long-run equilibrium relationship, normalized to gdpgr, is given in equation 5. (Note standard errors in parenthesis). This is the long-run dynamic relation between economic growth rate and the two sources of financing investment, given all macroeconomic indicators as constant.

$$
g d p g r=\underset{(0.06488)}{0.13309}+\underset{(0.08602)}{0.14062} \operatorname{sav}+\underset{(0.54155)}{4.36686} \text { odar } \ldots .5 .0
$$

The result in equation 5.0 shows that, holding all macroeconomic indicators constant, there is a positive long-run relationship between domestic saving and economic growth; likewise between foreign assistance and economic growth. An increase in both gaps, the domestic and the foreign, will increase economic growth. That is the long-run marginal effects of saving rate and foreign assistance rate on economic growth rate are positive when macroeconomic variables like exchange rate, inflation rate and export rate are all stable. 
Table 5: Unrestricted ECM (Short-run Dynamics)

\begin{tabular}{|l|l|l|l|l|}
\hline Dependent Variable: D(GDPGR) \\
\hline & Coefficient & Std. Error & t-Statistic & Prob. \\
\hline ECM(-1) & -0.3659 & 0.488972 & -0.7483 & 0.4619 \\
\hline D(GDPGR(-1)) & -0.222393 & 0.550008 & -0.40435 & 0.6897 \\
\hline D(GDPGR(-2)) & -0.288069 & 0.425629 & -0.67681 & 0.5053 \\
\hline D(SAV(-1)) & -0.172391 & 0.185609 & -0.92879 & 0.3626 \\
\hline D(SAV(-2)) & -0.19712 & 0.169903 & -1.16019 & 0.2579 \\
\hline D(ODAR(-1)) & -0.419844 & 1.510499 & -0.27795 & 0.7835 \\
\hline D(ODAR(-2)) & -0.408473 & 0.799684 & -0.51079 & 0.6144 \\
\hline C & 0.29928 & 1.363449 & 0.219502 & 0.8282 \\
\hline R-squared & 0.343814 & & & \\
\hline
\end{tabular}

The interpretation of the error correction mechanism in Table 5 is as follows. The presence of cointegration between GDPGR and the set of domestic saving and foreign assistance variables show that there exists a long run equilibrium relationship in the model. The negative value of the ECM coefficient $(-0.3659)$ confirms that there is disequilibrium in economic growth rate in the short run which the set of variables in the model are trying to correct in the long run. That is there is change in economic growth rate (measured by GDPGR), DGDPGR $\neq \mathbf{0}$, if either there was a disequilibrium last period (ECM $\neq \mathbf{0})$ in which case some changes in all the exogenous variables (domestic saving and foreign aid) are necessary to restore equilibrium, or there was a change in the exogenous variables in the current period which because of the equilibrium condition (as shown in the cointegrating equation), implies that GDPGR should also change.

The rule of thumb is that if the coefficient of ECM is greater than zero (positive) it means there is a surplus of the dependent variable, which is economic growth rate, a reduction in savings and foreign aid is therefore required to restore equilibrium in the long run. But if otherwise the coefficient is less than zero (negative) as it is in Table 5, there is deficiency in growth rate of GDP and increase is required through the set of exogenous variables to restore equilibrium in the long run. The results in Table 5 thus show that there is disequilibrium in growth rate of gdp in the short-run which the set of saving and foreign assistance variables tend to be correcting. The speed at which this adjustment is made in the short run is captured by the magnitude of the ECM coefficient. The speed here is 0.3659 , which is slow. That means improvement in the domestic saving and inflow of foreign assistance conditions in the short run can correct about $36.6 \%$ of the deficiency in economic growth rate in the long run, given that all other macroeconomic indicators are stable.

Since all variables in equation 4 are not stationary at the same level as shown in the result in Table 2, the condition for Johansen co-integration technique is not met for estimating equation 4, ARDL Bound testing cointegration approach developed by Peseran, Shin and Smith (2001) was preferred to test the long-run equilibrium relationship among the variables.

The bound test regression is theoretically specified in two ways, the original and the E-views version. The original version of the specification in equation 4.0 is as shown below:

$\Delta\left(\log g d p g r_{t}\right)=\beta_{0}+\sum \beta_{j} \Delta\left(\log g d p g r_{t-j}\right)+\sum \gamma_{1} \Delta\left(\log \inf _{t-j}\right)+\sum \gamma_{2} \Delta\left(\log \operatorname{exr}_{t-j}\right)+\ldots \ldots \ldots$

$\ldots \ldots+\sum \gamma_{3} \Delta\left(\log \exp r_{t-j}\right)+\sum \gamma_{4} \Delta\left(\log s a v_{t-j}\right)+\sum \gamma_{5} \Delta\left(\log o d a_{t-j}\right)+\theta_{0} \log \left(g d p g r_{t-1}\right)+\ldots \ldots$

$\ldots . .+\theta_{1} \log \left(\right.$ inf $\left._{t-1}\right)+\theta_{2} \log \left(\right.$ exr $\left._{t-1}\right)+\theta_{3} \log \left(\exp r_{t-1}\right)+\theta_{4} \log \left(\operatorname{sav} v_{t-1}\right)+\theta_{5} \log \left(\right.$ oda $\left.a_{t-1}\right)+e_{t}$

where $j=1,2,3 \ldots \ldots$...

Equation 6 is the ARDL model of the "economic growth rate - two gap" relationship which is also known as the "unrestricted ECM". The lagged first difference AR variables are the short-run dynamics while the DL variables are the long run impacts. Using E-views 9 version, the maximum lags for the endogenous and exogenous variables were selected in such a way that the degree of freedom (defined as n-k) was not less than 30. The Linear Trend option was selected because the two major variables and most of the control variables were trended. The appropriate lag selection for the optimal lag was determined using the Schwartz (SC) criterion. An $\operatorname{ARDL}(2,3,2,0,1,0)$ was selected that is, 2 lags was selected as optimal for gdpgr, 3 lags for exr, 2 lags for sav, zero lag for inf, 1 lag for expr and zero lag was selected for odar. The result is shown in Table 6 in Appendix 1. It is also the test regression on which the Bound test was conducted.

The Bound test was conducted on the unrestricted ECM in Appendix 1, by conducting the F statistics of the hypothesis, $H_{0}: \theta_{0}=\theta_{1}=\theta_{2}=0$ against the alternative. As a check we perform a "Bounds" F-test" of $H_{0}=0$, if the F-statistic is greater than the Critical Value Bounds for the upper bound I(1), this would support the conclusion that there is a long-run relationship between the variables. If the computed $F$ - statistic falls below the lower bound we would conclude that the variables are $\mathrm{I}(0)$, so no cointegration is possible by 
definition. Finally if the $\mathrm{F}$ - statistics falls between the bounds, the test is inconclusive, we may rely on the result of Granger causality and/or the short-run analysis. The result of the Bound Test is shown in Table 7.

Table 7: ARDL Bound Test

\begin{tabular}{|l|l|l|}
\hline \multicolumn{4}{|l|}{ Included observations: 31} \\
\hline $\mathrm{H}_{0}$ : No long-run relationships exist \\
\hline Test Statistic & Value & $\mathrm{K}$ \\
\hline F-statistic & 5.887579 & 5 \\
\hline Critical Value Bounds \\
\hline Significance & I0 Bound & I1 Bound \\
\hline $10 \%$ & 2.75 & 3.79 \\
\hline $5 \%$ & 3.12 & 4.25 \\
\hline $2.50 \%$ & 3.49 & 4.67 \\
\hline $1 \%$ & 3.93 & 5.23 \\
\hline
\end{tabular}

In Table 7.0, the value of our F-statistic is 5.887579, which is greater than the upper bound at both 5\% and $1 \%$ level of significance. As the value of our $\mathrm{F}$ statistic exceeds the upper bound we conclude that there is evidence of a long-run relationship among the variables. We can therefore estimate both the short-run and the long-run dynamics form the underlying ARDL result of Appendix 1. The result is shown in Table 8.

Table 8: ARDL Cointegrating and Long -run Forms

\begin{tabular}{|l|l|l|l|l|}
\hline \multicolumn{2}{|l|}{ Cointegrating Form (Short-run Dynamics) } \\
\hline Variable & Coefficient & Std. Error & t-Statistic & Prob. \\
\hline $\mathrm{D}(\mathrm{GDPGR}(-1))$ & 0.394863 & 0.219407 & 1.799681 & 0.0908 \\
\hline $\mathrm{D}(\mathrm{EXR})$ & 0.017992 & 0.077785 & 0.231307 & 0.82 \\
\hline $\mathrm{D}(\mathrm{EXR}(-1))$ & -0.19212 & 0.135691 & -1.41583 & 0.176 \\
\hline $\mathrm{D}(\mathrm{EXR}(-2))$ & -0.13645 & 0.090028 & -1.51568 & 0.1491 \\
\hline $\mathrm{D}(\mathrm{SAV})$ & 0.657747 & 0.234515 & 2.804712 & 0.0127 \\
\hline $\mathrm{D}(\mathrm{SAV}(-1))$ & 0.401989 & 0.131741 & 3.051354 & 0.0076 \\
\hline $\mathrm{D}(\mathrm{INF})$ & -0.00733 & 0.066447 & -0.11033 & 0.9135 \\
\hline $\mathrm{D}(\mathrm{EXPR})$ & -0.44179 & 0.185889 & -2.37663 & 0.0303 \\
\hline $\mathrm{D}(\mathrm{ODAR})$ & -2.5022 & 1.256908 & -1.99076 & 0.0639 \\
\hline $\mathrm{D}($ @ TREND()) & -1.07639 & 0.376221 & -2.86106 & 0.0113 \\
\hline CointEq(-1) & -1.05837 & 0.503239 & -2.10313 & 0.0516 \\
\hline Long Run Coefficients & Coefficient & Std. Error & t-Statistic & Prob. \\
\hline Variable & 0.180186 & 0.100383 & 1.794985 & 0.0916 \\
\hline EXR & -0.34336 & 0.280547 & -1.2239 & 0.2387 \\
\hline SAV & -0.00693 & 0.060938 & -0.11367 & 0.9109 \\
\hline INF & 0.237233 & 0.12385 & 1.915489 & 0.0735 \\
\hline EXPR & -2.36419 & 2.198423 & -1.0754 & 0.2981 \\
\hline ODAR & 13.01919 & 8.630231 & 1.508556 & 0.1509 \\
\hline C & -1.01702 & 0.60574 & -1.67898 & 0.1126 \\
\hline @TREND & & & \\
\hline
\end{tabular}

The ARDL Results in Table 8 present both the short-run dynamic, that is error correction mechanism and the long-run dynamics of the relationship between foreign aid and economic growth given a set of macroeconomic indicators that are unstable. The results are interpreted in three dimensions. The first is the short-run adjustment of economic growth to changes in foreign aid, exchange rate, domestic saving, inflation rate and export growth rate simultaneously. This is the components of the short-run dynamic captured by the coefficients of cointEq.1, which is the ECM (-1) coefficient. The coefficient is -1.0584 , significant at $10 \%$ as shown by the probability (0.0516). This implies that the adjustment is in the right direction and the speed of adjustment is 1.0584. Economic growth in Nigeria is deficient, as shown by the negative sign of the ECM coefficient. This deficiency is gradually restored through changes in the set of exogenous variables over time. The speed at which economic growth adjust to this restoration is 1.0584 . The second influence is captured by the coefficients of the short-run and long-run marginal effects. These are measures of the short run and long-run impacts of the exogenous variables on economic growth. The results are summarized in Table 9

Table 9: Short-run and Long-run Marginal Impacts on Economic growth rate.

\begin{tabular}{|l|l|l|l|l|}
\hline & SHORT -RUN & LONG - RUN \\
\hline Coefficient & Relationship & Level of Significance & Relationship & Level of Significance \\
\hline ODAR & Negative & low level (10\%) & Negative & not significant \\
\hline EXR & Negative & not significant & Positive & low level (10\%) \\
\hline SAV & Positive & High level $(1 \%)$ & Negative & not significant \\
\hline INF & Negative & not significant & Negative & not significant \\
\hline EXPR & Negative & significant (5\%) & Positive & low level (10\%) \\
\hline
\end{tabular}




\section{VAR Forecasting Of Economic Growth Rate And Foreign Aids}

Part of the objectives of this paper is to forecast the three macroeconomic variables that relate the economy with the global economies. These are the GDP, EXR and ODA. We rely on the dynamic forecast using the impulse response function of the VAR. A VAR model describes the evolution of a set of $k$ variables (called endogenous variables) over the same sample period $(t=1, \ldots, \mathrm{T})$ as a linear function of only their past evolution. The variables are collected in a $\mathrm{k} \times 1$ vector $\mathrm{yt}$, which has as the ith element yi,t the time $\mathrm{t}$ observation of variable yi. For example, if the ith variable is GDP, then yi,t is the value of GDP at t. A (reduced) p-th order $\operatorname{VAR}$, denoted $\operatorname{VAR}(\mathrm{p})$, is

$$
y_{t}=c+\Phi_{1} y_{t-1}+\ldots \ldots+\Phi_{p} y_{t-p}+\varepsilon_{t}
$$

where $\mathrm{c}$ is a $\mathrm{k} \times 1$ vector of constants (intercept), $\Phi \mathrm{i}$ is a $\mathrm{k} \times \mathrm{k}$ matrix (for every $\mathrm{i}=1, \ldots, \mathrm{p}$ ) and $\varepsilon_{t}$ is a $\mathrm{k} \times 1$ vector of error terms The i-periods back observation yt-i is called the $i$-th lag of $y$. Thus, a pth-order VAR is also called a VAR with $p$ lags. $\{y t\}$ is covariance-stationary if Eyt and $E(y t-E y t)(y t-j-E y t-j$ )' are independent of $t$ for any $j$.

An important preliminary step in VAR and impulse response analysis is the selection of the lag order. In this paper we use some commonly used lag-order selection criteria to choose the lag order, such as AIC and the SC.All the criteria suggest on lag. The result of the VAR is shown in Appendix II.

\section{Impulse Response Function}

The impulse response function of VAR is to analysis dynamic effects of the system when the model received an impulse, innovation or a shock. For our VAR model, we have four macroeconomic variables, GDPGR, EXR and ODAR. This section presents a ten-period forecast of the response among the variables if there is a shock to any of them. In order to display the response function clearer, we plot the chart as in figure 2.

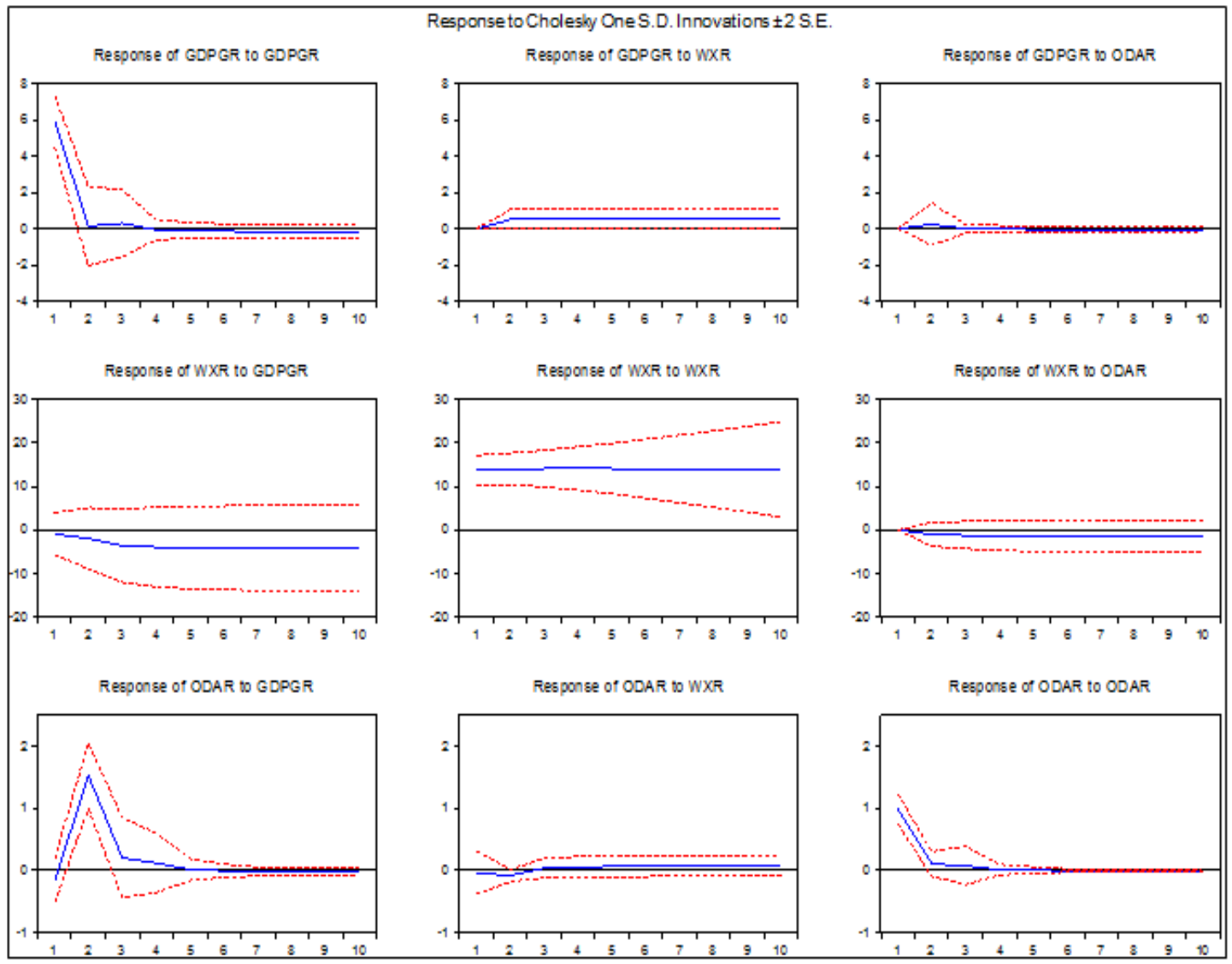

Figure 2: Impulse Response Function of GDPGR, EXR and ODAR

From figure2, the response of GDP growth rate to a one standard deviation shock to exchange rate clusters below one. That means a unit shock to exchange rate generate a less proportionate response from economic growth rate. Onn the other hand, a unit shock to economic growth rate generates a more than proportionate negative response from exchange rate. That is for the next ten periods, any shock to economic growth will continue to worsen exchange rate in the Nigeria economy. 
The response of GDP growth rate to the official development assistance for the ten year period seems to be very low and negative. A one standard deviation shock to official development assistance generates a negative response from positive fluctuation in the first five periods and then become negative. When the impulse is ODAR, the response of exchange rate is all negative at each responsive period; the values fluctuate around the line zero. On the other hand the response of ODAR to shock received by exchange rate is only negative at the first two periods and positive for the other periods. The values also clustered around zero. The question now is which variable is useful to forecast economic growth rate, given the impulse responses above? We use Granger causality test to evaluate the forecast ability of the time series variables. a technique for determining whether one time series is useful in forecasting another. It can determine whether there is causality relationship between variables. The result is presented in Table

Table 10: Granger Causality Test

\begin{tabular}{|l|l|l|l|l|}
\hline Null Hypothesis: & Obs & F-Statistic & Prob. & Decision \\
\hline EXR does not Granger Cause GDPGR & 33 & 4.54564 & 0.0413 & Reject the null \\
\hline GDPGR does not Granger Cause EXR & & 0.22523 & 0.6385 & Accept the null \\
\hline ODAR does not Granger Cause GDPGR & 35 & 0.57808 & 0.4526 & Accept the null \\
\hline GDPGR does not Granger Cause ODAR & & 65.9331 & 0.0000 & Reject the null \\
\hline ODAR does not Granger Cause EXR & 33 & 0.56045 & 0.4599 & Accept the null \\
\hline EXR does not Granger Cause ODAR & & 0.80542 & 0.3766 & Accept the null \\
\hline
\end{tabular}

The direction of causality from Table 10 runs from exchange rate to economic growth rate. That means, the stability of exchange rate can be used to predict how stable the growth of the Nigeria economy would be. In like manner, the direction of causality runs from economic growth and exchange rate to official development assistance. This also implies that the macroeconomic conditions of economic growth rate and exchange rate stability are the major predictors of effectiveness of foreign aids (official development assistance).

\section{Conclusion}

The following inferences are drawn from the all the analyses in this study:

- There is disequilibrium in the growth rate of GDP in Nigeria.

- In the short-run the combination of domestic saving and foreign aid variables tend to correct the disequilibrium but at slow speed of adjustment.

- Given all macroeconomic indicators in Nigeria as stable, domestic saving and foreign aid are more effective to increase the growth of the economy.

- With the unstable nature of macroeconomic indicators in Nigeria especially, the increasing rate of inflation and exchange rates and the low export rate, official development assistance, that is foreign aid, tend to be impacting negatively on the economy rather than positive. That means foreign aid becomes less effective in the face of unstable exchange rate, inflation rate and low export.

- Domestic saving, on the other hand, becomes insignificant to increase economic growth rate when there is high inflation rate. This is justified as people prefer to spend money rather than save when there is continuous rise in inflation rate.

- An improvement in Export rate through foreign direct investment would increase economic growth rate in the long-run. But the present status of export in the country has not significantly increase the growth rate of the economy. It has a negative impact on economic growth. This may be justified from the angle of overdependence on imported consumer goods and raw materials in the country.

- Macroeconomic conditions of economic growth rate and exchange rate stability are the major predictors of effectiveness of foreign aids (official development assistance) in Nigeria.

- Any shock that destabilizes exchange rate in Nigeria will reduce the growth rate of the economy. This probably one of the causes of economic recession currently witnessed in the country.

The findings in this study, that foreign aid has positive relationship with economic growth especially in a stable macroeconomic environment is in line with the findings of [11], [5] and [6]. Also findings of [13] support it.

Policy measures that will diversify the economy, improve export and encourage a more stable exchange rate will allow a more effective utilization of foreign aids in the economy. Foreign aid flows should be used more on imports of capital goods rather than imports of consumptions goods. The strategy for export diversification must be adopted to attain the best possible outcomes.

An important task for the government of Nigeria now is to introduce effective financial policies to improve the efficiency of the domestic financial sector as a pre-requisite for the achievement of positive spillovers of foreign capital inflows. 


\section{References}

[1]. Chenery, H.B and Strout, A.M (1966), "Foreign Assistance and Economic Development" American Economic Review, 56, 679733.

[2]. CBN (2017), Central Bank of Nigeria, online publication, available at http//www.tradingeconomics.com.UNCTAD (2012)

[3]. Salisu (2007) "Examined aid, macroeconomic policy environment and growth in sub-saharan Africa". Pakistan Journal of Applied Economics, Vol.20 Nos. 1 \& 2 (1-12), 2010.

[4]. Fasanya and Onakoya (2012) "Impact of foreign aid on economic growth in Nigeria. International Journal of Economics and Financial issues. Vol. 2, No. 4, pp. 423- 431

[5]. Yakama (2013) "Effect of foreign aid on growth in West Africa. Working papers in Management Birkbeck, Department of Management BWPMA 1303.

[6]. Karras (2006) "Foreign aid and growth in per capita GDP in developing countries. Journal of International Development Vol. 18, Issue 1, pg 15-28

[7]. Gomance, Girma and Morrissay (2005) "aid and economic growth in sub-saharan African. World Institute for Development Economics Research, Research paper No 2005/60

[8]. Gruben and McLead (1998)“capital flows and growth along with savings for 18 Asia and American developing countries. Qurterly Review of Economics and Finance, 38(3), 287- 299.

[9]. Duc (2006) "Impact of foreign aid on economic growth in developing countries. Openstax-CNX and licensed under the creative commons Attribution licence 2.0 Pg 01-22.

[10]. Peter N. Mba (2012) "Interplay of foreign aid, external debt and economic growth in Nigeria. International Journal of Economics and Finance; Volume 4, no 8; ISSN 1916-671X E-ISSN 1916-9728.

[11]. Chinecherem, Ezerekwe and Uju (2015) "Impact of foreign aid on capital generation in Ngieria. International Journal of Economics, commerce and management; vol iii,, issue 9, September 2015. ISSN 23480386.

[12]. Hemc and Basnet (2013), examined foreign aid, Domestic savings and Economic growth in South Asia. International Business \& Economic Research Journal- November 2013 volume 12, number 11.

[13]. Javid and Qayyum (2011) "Interactive effect of aid and policy suitable economic growth in Zimbabwe. The Authors Journal Compilation: African Development Bank.

[14]. Arawomo, Badejo and Oshota (2015),examined the impact of foreign aid and domestic savings on economic growth in the WAMZ countries. Journal of Economics and Business Research vol. 21 No 2 (2015)

[15]. Ekwe and Nyiama (2014) "Impact of foreign capital flows on the growth performance of the Nigeria economy. International Journal of Economics and Finance: Vol. 6, No 4, Pg 103-109.

[16]. Stella M. and Ditimi A. (2014), The Link between foreign aid and economic growth in Nigeria. International Journal of Economics practices and theories, Vol.4, No 6, 2014, e-ISSN 2247-7225.

[17]. Saltz (1992) Foreign direct investment and economic growth in 68 developing countries. RivistaInternationale Di Science Economichee Commerciali, 39, 617-633.

[18]. De Mcllo (1999) "Nexus between foreign direct investment and economic growth in 32 countries (15 OECD and 17 non OECD). Oxford Economic papers, 51(1): 133-152.

[19]. Tiwari (2011) "Effectiveness of foreign aid, foreign direct investment and economic growth in selected 28 Asian countries. Global Economy Journal, Vol. 11,pg 1-28, 2011

[20]. [21]Fayissa and El-Kaissy (1999), Foreign aid and Economic Growth of Developing Countries (LDCs): Further Evidence, Studies in Comparative International Development.

[21]. Dhakal, Upadlyaya and Upadhyay (1996) "Causality between foreign aid and economic growth in four Asian and four African Countries. Rivista Internationale Di Science Economiche e Commerciali, 43: 597-606.

\section{APPENDIX I}

Table 6: ARDL RESULT

\begin{tabular}{|l|l|l|l|l|}
\hline \multicolumn{5}{|l|}{ Dependent Variable: GDPGR } \\
\hline Selected Model: ARDL(2, 3, 2,0,1,0) \\
\hline Variable & Coefficient & Std. Error & t-Statistic & Prob.* \\
\hline GDPGR(-1) & 0.336488 & 0.37092 & 0.907172 & 0.3778 \\
\hline GDPGR(-2) & -0.394863 & 0.219407 & -1.79968 & 0.0908 \\
\hline EXR & 0.017992 & 0.077785 & 0.231307 & 0.82 \\
\hline EXR(-1) & -0.155857 & 0.124406 & -1.25281 & 0.2283 \\
\hline EXR(-2) & 0.192115 & 0.135691 & 1.415834 & 0.176 \\
\hline EXR(-3) & 0.136453 & 0.090028 & 1.515675 & 0.1491 \\
\hline SAV & 0.657747 & 0.234515 & 2.804712 & 0.0127 \\
\hline SAV(-1) & -0.619163 & 0.189705 & -3.26381 & 0.0049 \\
\hline SAV(-2) & -0.401989 & 0.131741 & -3.05135 & 0.0076 \\
\hline INF & -0.007331 & 0.066447 & -0.11033 & 0.9135 \\
\hline EXPR & -0.44179 & 0.185889 & -2.37663 & 0.0303 \\
\hline EXPR(-1) & 0.692872 & 0.201137 & 3.444774 & 0.0033 \\
\hline ODAR & -2.502196 & 1.256908 & -1.99076 & 0.0639 \\
\hline C & 13.77918 & 5.201785 & 2.648932 & 0.0175 \\
\hline
\end{tabular}


Macroeconomic Fluctuations, Foreign Aid Shocks and the Forecast of Economic Growth Rate In

\begin{tabular}{|l|l|l|l|l|}
\hline @ TREND & -1.076392 & 0.376221 & -2.86106 & 0.0113 \\
\hline \multicolumn{5}{|l|}{} \\
\hline R-squared & 0.701862 & Mean dependent var & & 5.4 \\
\hline Adjusted R-squared & 0.440991 & S.D. dependent var & & 6.227091 \\
\hline S.E. of regression & 4.655804 & Akaike info criterion & & 6.22045 \\
\hline Sum squared resid & 346.8242 & Schwarz criterion & & 6.914314 \\
\hline Log likelihood & -81.41697 & Hannan-Quinn criter. & & 6.446632 \\
\hline F-statistic & 2.690456 & Durbin-Watson stat & & 2.169807 \\
\hline Prob(F-statistic) & 0.030333 & & \\
\hline
\end{tabular}

\section{APPENDIX II}

\begin{tabular}{|c|c|c|c|}
\hline \multicolumn{4}{|c|}{ Vector Autoregression Estimates } \\
\hline & GDPGR & WXR & ODAR \\
\hline \multirow[t]{3}{*}{ GDPGR(-1) } & 0.033673 & -0.21579 & 0.260178 \\
\hline & -0.18328 & -0.42894 & -0.03116 \\
\hline & [0.18372] & {$[-0.50308]$} & [ 8.34888] \\
\hline \multirow[t]{3}{*}{ WXR(-1) } & 0.036992 & 1.010938 & -0.00578 \\
\hline & -0.01852 & -0.04334 & -0.00315 \\
\hline & [ 1.99776$]$ & [ 23.3277] & {$[-1.83439]$} \\
\hline \multirow[t]{3}{*}{ ODAR(-1) } & 0.233621 & -1.05136 & 0.105828 \\
\hline & -0.59113 & -1.38346 & -0.10051 \\
\hline & {$[0.39521]$} & {$[-0.75995]$} & [ 1.05291$]$ \\
\hline \multirow[t]{3}{*}{$\mathrm{C}$} & 2.390998 & 5.805684 & -0.48345 \\
\hline & -1.56036 & -3.65182 & -0.26531 \\
\hline & [ 1.53234$]$ & {$[1.58980]$} & {$[-1.82220]$} \\
\hline R-squared & 0.165923 & 0.957305 & 0.716675 \\
\hline Adj. R-squared & 0.079639 & 0.952889 & 0.687366 \\
\hline F-statistic & 1.922984 & 216.7475 & 24.45201 \\
\hline
\end{tabular}

